\title{
Banff 1996
}

\author{
By Gerald Pratley \\ Spring 1997 Issue of KINEMA
}

THE DOMINANT PERSONALITIES at the 17th Banff TV Festival this year were, not surprisingly, British and American: Melvyn Bragg of the South Bank Show and Steven Bochco, writer and producer; the credits of these two creative celebrities hardly need repeating here. The most impressive presence, in numbers and intelligence, was the delegation from Boston's WGBH, the station chosen by the Festival to receive its Outstanding Achievement Award.

With President and General Manager, Henry Becton Jr.; Vice-President for National Programming, Peter McGhee; and Vice-President for Special Telecommunications Services, Brigid Sullivan; and their associates including Rebecca Eaton, producer of Mystery and Masterpiece Theatre, here was a group of broadcasters dedicated to the principles of Public Broadcasting and fighting determinedly to maintain their place on U.S. television screens despite the reduction in funding from the National Endowment for the Arts.

"When we say" remarked Henry Becton, "that if PBS doesn't show most of the programmes and films we put on, without being interrupted by commercials, then who will? This is perfectly true. The specialty channels on cable are just that -- they specialise in certain areas. We are committed to everything of value to the arts and society."

In conversation later about commercial sponsorship with Rebecca Eaton I mentioned that few viewers could object to the delightful Mobil introductions to Mystery and Masterpiece, both imaginative and in good taste. She agreed but went on to say that for reasons not made clear, Mobil, a wealthy company, was dropping its sponsorship of Mystery forcing WGBH to look elsewhere for a new supporter. Many viewers are unaware that the witty cartoon-like b\&w introduction preceding Diana Rigg was drawn by Derek Lamb, formerly of the NFB (National Film Board of Canada). Ms Eaton promises us a compelling Diana Rigg playing Mrs. Danvers in the new version of Daphne du Maurier's Rebecca.

And among the discussions and tributes who and what do we get from our own country? The pathetic Perrin Beatty, President of the CBC, completely out of his depth and blathering on in convoluted phrases and tortuous sentences about "assembling audiences" (where, in a church hall?) for the absurdly self-promoting, self-praising, new CBC programming schedule announced during the festival as being "97\% all-Canadian".

Why only now all-Canadian? The CBC should always be all-Canadian and was at one time. How this former politician and bureaucrat could sit on stage with the representatives of WGBH and claim that the CBC is a "great public broadcaster" when its programmes are ripped to pieces by odious, for the most part, commercials and to be so pleased with this intolerable state of affairs is shameful and a frightening foretelling of the unchanging future of the now ridiculous CBC. If the corporation were to rid itself of deadwood presently occupying dead chairs in dead offices there would be no need to allow advertisers to control and to ruin good programmes with their insensitive intrusions.

We were redeemed at times by Laurier LaPierre whose conversations with delegates revealed his opinions about the shortcomings of our broadcasting systems -- although at times his confrontational assault on his guests could be somewhat pompous and overbearing; probably brought on by his exasperation over the "Canadian condition". But he always knew what he was talking about, unlike several of our panellists.

If Banff made anything clear at its discussions to those participating it was that we are a puzzlement, if not a laughing stock, to the world over a state broadcaster which has a foot in either camp. And as for the matter of communications, the subject of many panels, just speak to filmmakers, tv producers, writers and the rest, about communicating with the CBC's "decision- making departments" and their heads and the answer is always the same: there are no answers, no replies to letters, faxes, telephone calls or to any attempts made to discuss ideas and proposals. Those finally accepted are the results of months, if not years, of wearying, dehumanising, humiliating efforts at getting responses from reluctant, incompetent and unimaginative representatives. 
The Banff Festival is certainly a delightful and rewarding event to be at mainly because it is an occasion at which everyone attending can meet those whom they came to see. There is time for producers, distributors, programmers, teachers, writers, the media, everyone in film and television, to sit and talk in the large and comfortable delegates' room without everyone looking over shoulders to see whether there are more "important" people they should be talking to.

Asked if this was an improvement over working at Berlin, Cannes, and the world's other over- large festivals, Jan Rofekamp, Fil Fraser, Jim Murphy, Rudy Buttignol, Paul Gratton, Ted Childs, Pat Ferns and many more among the over one thousand delegates, agreed that the pace and atmosphere of the festival are conducive to good relations and firm and prompt appointments. It is the leading festival when it comes to providing access to broadcasters and money for programming.

The physical setting of the festival at the wondrous old-world Banff Springs Hotel, could not be more convenient, well-laid out and organised. Everything is in one place; with an imaginatively decorated Ballroom where panel discussions are held (relayed on large tv monitors), a cinema for video and film screenings (in discussions with the producers), and several smaller rooms for alternate talks. These frequently overlapped and placed some panellists at disadvantages: one good panel drew participants away from the other -- just as interesting perhaps but one appealing more than the other.

An example was the interesting talk between the co-producers of Cinar of Montreal and WGBH about Albert, their latest animation series. There were ten people in the audience while several hundred were attending the discussion in the Ballroom. It must be disheartening for participants to come from far away only to find such a small group in attendance. The other drawback is the lack of a screening programme. None of the winning films (announced on opening night -- a great idea) or the nominated programmes (pre-seen and decided upon pre-festival by the judging panel) are shown. Delegates wishing to see them go to the video library (especially set-up) to book a title and a room to watch them in.

But this is time-wasting and often impossible because the videos are out and the rooms are full. President Jerry Ezekiel, always to be seen about and available for meetings and conversations, explained that there had been a screening programme but it was dropped due to lack of space. It would perhaps be better to use the cinema all day and evenings to show the films (or programmes) and this would be the only alternative to the discussion sessions. The choices to be made would then be easier without visitors facing almost empty auditoriums. The only disappointment for me at Banff was to come away with so many of the entries unseen.

I have attended over two hundred festivals around the world over thirty-five odd years and none, not even Cannes, has such impressive, magical and majestic surroundings. It is a place which lifts the spirits, where everyone at the festival is warm and welcoming, where women actually smile when passing, where everyone talks to everyone else, strangers or not, and the evening celebrations, from Karaoke to the BBQ, are feasts of good food and good cheer taking place among elegant and lovely surroundings.

But most important of course, is the amount of work carried out, connections made, friendships began, and hopes raised that projected ideas and associations will materialise in the months to come. It is a gathering at which the budget is well spent with the results being apparent. Glitz and glamour, no, but friendship and a perceptive understanding of intelligent programming, yes.

\section{Author Information}

Gerald PRATLEY, OC, LLD, started his career as film critic with the CBC. In 1969, he founded the Ontario Film Institute which he directed until 1990. He has written several books and numerous articles on film, including Torn Sprockets, a history of Canadian cinema. He taught Film History in universities in Toronto and Waterloo, Canada and holds three honorary degrees from Canadian and US universities.

Gerald A. Pratley (1923-2011) was born and educated in London, England, and came to Canada in 1946. He started working in Toronto for the $\mathrm{CBC}$ as a scriptwriter. He was drawn toward working in motion pictures, and became, in 1948, the CBC's first film critic and commentator. 
Gerald Pratley broadcast three programmes a week, Pratley at the Movies, The Movie Scene, Music From the Films, and others, until 1975. During this time he also became the first post-war chairman of the Toronto Film Society, chairman of the Toronto and District Film Council and co-founder of the A-G-E Film Society and correspondent for international magazines such as Films and Filming, Film In Review, Variety, Hollywood Quarterly and International Film Guide. During the 1950s he wrote for Canadian Film Weekly and Canadian Film Digest.

He became known as a speaker on all aspects of motion picture art and industry, and was invited to teach film history at the University of Toronto, York University, University of Waterloo, Seneca College and Ryerson Polytechnical University, with individual lectures being given at many other Canadian and US universities and colleges. He has served as a member of various judging panels of competitions and festivals, being one of the members of the first Canadian Film Awards in 1949.

From 1970 to 1975 he was the director of the Stratford (Ontario) International Film Festival, and from 1969 to 1976 he was Chairman of the International Jury of the Canadian Film Awards. He has attended all the world's leading festivals of film, and in particular, for 30 years, the Cannes Festival as CBC correspondent. He has written six books, The Films of Frankenheimer: Forty Years in Film; The Cinema of John Frankenheimer; The Cinema of Otto Preminger; The Cinema of David Lean; The Cinema of John Huston, and Torn Sprockets, a history of the Canadian cinema.

Gerald Pratley has served on the Advisory Boards of the film departments of Ryerson Polytechnical University and Humber College, and as a member of the programme committee of TV Ontario. In 1968 he became the founder-director of the Ontario Film Institute of the Province of Ontario, an organization which has distinguished itself in archival holdings and public service and is known since 1990 as the Cinematheque of Ontario. He taught Film History courses at the Department of Film and Photography, Ryerson Polytechnic University, Toronto and the University of Waterloo.

In 1984, Gerald Pratley was made a Member of the Order of Canada and in 2003 Officer of the Order of Canada for his service to Canada through film appreciation. He holds Honorary Degrees in Letters and Fine Arts from York and Waterloo Universities (Ont., Canada) and Bowling Green State University (Ohio, USA).

In 2002, Gerald Pratley received a Special Genie Award from the Academy of Canadian Cinema \& Television in recognition of his lifelong dedication to the promotion and his exceptional support of Canadian cinema.

He died on 14 March 2011 in Ontario, Canada. 